УДК 57.044:550.46

\title{
ВЛИЯНИЕ ПРИРОДНЫХ ФАКТОРОВ НА СОДЕРЖАНИЕ РТУТИ В ОЗЕРАХ СЕВЕРА ЗАПАДНОЙ СИБИРИ
}

\author{
Захарченко Александр Викторович1, \\ avzakh@gmail.com
}

\author{
Пасько Ольга Анатольевна², \\ helgapas@mail.ru
}

Тигеев Александр Анатольевич1, ttruubbaa@mail.ru

\author{
1 Тюменский научный центр Сибирского отделения Российской Академии Наук, \\ Россия, 625026, Тюмень, ул. Малыгина, 86. \\ 2 Томский политехнический университет, \\ Россия, 634050, Томск, пр. Ленина, 30.
}

\begin{abstract}
Актуальность исследования обусловлена тем, что ртуть участвует в глобальном планетарном биогеохимическом цикле $и$ входит в пищевые цепи с накоплением в организмах хищных видов животных и у коренного населения. В отношении к территории Западной Сибири информация о содержании ртути в озерах не достаточно полная, а обобщения сделаны на малых выборках, что делает актуальным фоновые изучения содержания ртути в среднетаежных озерах на репрезентативной выборке.

Целью исследования является анализ и обобщение фоновых мониторинговых наблюдений, как за общим содержанием ртути донных отложений, так и её содержанием в поверхностных водах озер, в зависимости от природных фракторов в условиях средней тайги в пределах Ханты-Мансийского автономного округа.

Объект: фоновая концентрация растворенной $\mathrm{Hg}$ и ртути в донных отложениях озер. Изучено 95 озер, 322 пробы донных отложений, отобранных в разное время.

Методы: атомно-адсорбционная спектрометрия (метод "холодного пара») определения ртути в аккредитованных лабораториях в соответствии с методическими рекомендациями. Использованы данные фонового экологического мониторинга с 2007 no 2011 г2.

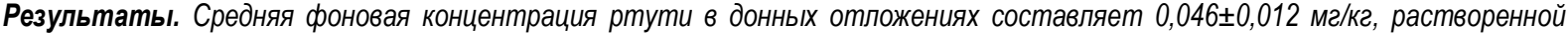
ртути - 0,025 0,014 ме/ке. Наибольшая концентрация $\mathrm{Hg}$ выявлена в элювиальной и трансэлювиальной позициях, наименьшая - в супераквальных ландшафртах. Концентрация $\mathrm{Hg}$ имеет максимальное значение в озерково-грядово-мочажинном комплексе торфяяных болот, а самое низкое - в донных отложениях озер на минеральных почвах. Наблюдается тенденция увеличения концентрации ртути в донных отложениях озер от зоны тундры, северной тайги до подзоны средней тайги. Но нарастает заболоченность территорий с юга на север, что способствует увеличению содержания ртути в донных отложениях озер $(R=0,4)$. Отмечается увеличение растворенной ртути в озерах с запада на восток (по долготе) $(R=0,6)$. Оценка динамики изменения содержания ртути в донных отложениях позволяет заключить, что в зимний период содержание ртути выше по сравнению с летним периодом. Концентрация растворенной ртути возрастает с запада на восток, но ртуть донных отложений этой закономерности не соответствует.
\end{abstract}

\section{Ключевые слова:}

Ртуть, донные отложения, озера, ландшаффтно-географические фракторы, динамика, Субарктика.

\section{Введение}

Длительная история исследования природных ресурсов Севера обусловлена возможностью их широкого использования. Освоение крупных запасов полезных ископаемых создает конкурентную среду для многих государств региона, влияет на климат и состояние экосистем северного полушария Земного шара [1]. Глобальное потепление климата вызывает необходимость разработки новых логистических решений в стратегии развития региона. Необходим учет тенденции развития производства, роста численности населения и развития международной торговли по Северному морскому пути. Экономические и геополитические предпосылки способствуют росту антропогенной нагрузки на уникальные арктические экосистемы и повышают актуальность региональных экологических исследований.
Особой экотоксикологической проблемой для исследований представляется изучение миграции ртути в связи с её участием в глобальном планетарном цикле [2], высокой токсичностью и выраженной кумулятивной способностью. Накопление ртути в пищевых цепях представляет риск для здоровья местных жителей, а также диких животных, Арктики и Субарктики [3]. Выявлено, что в тканях хищников, занимающих верхние уровни пищевой цепи в Арктике, ртуть почти исключительно метилирована. В крови и жировой ткани коренного населения также отмечено повышенное содержание метилртути (MeHg) [4]. Циклы $\mathrm{MeHg}$ в Арктике описаны для водно-болотных комплексов, озер и тундровых водосборов [5]. Ртуть способна к биоаккумуляции в трофических системах - в водоемах и в сухопутных биогеоценозах $[4,6]$. 
Поступление ртути в естественные ландшафты происходит несколькими путями, прежде всего, в ходе внутрипочвенного выветривания с переходом $\mathrm{Hg}(+2)$ в молекулярную ртуть $\mathrm{Hg}(0)$ в окислительных условиях или монометилртуть $\mathrm{CH}_{3} \mathrm{Hg}^{+}$в восстановительной среде [7]. Кроме того, $\operatorname{Hg}(0)$ поступает из мантии в виде паров вдоль разломов земной коры. Источником повышенного поступления ртути в район Карского моря (полярная станция Андерма) в 2010-2011 гг. стало извержение вулканов в Исландии [8]. С развитием горнодобывающей промышленности, металлургии, энергетики формируется дополнительный мощный антропогенный источник ртути [9]; происходит её миграция из южных регионов в высокие широты. Источником ртутного загрязнения Арктики являются также лесные пожары в умеренных широтах [10].

Известно, что ртуть присутствует в атмосфере в парогазовой фазе и аэрозольном состоянии $\left(0,5-2,0 \mathrm{Hг} / \mathrm{M}^{3}\right)$ [7]; она депонирована в почвах $(0,005-1,275$ мг/кг), ледовом и снеговом покрове, в поверхностных водах содержится в растворах 0,09 мкг/дм ${ }^{3}$ и взвесях - до 0,23 мкг/дм ${ }^{3}$. В конечном итоге миграция ртути приводит к её осаждению и аккумуляции в илистой фракции донных отложений рек и озер $(0,05-0,1$ мг/кг). Микроорганизмы способны преобразовывать ртуть из металлоорганического комплекса в форме $\mathrm{Hg}(\mathrm{II})$ в $\mathrm{Hg}(0)$ или метилртуть (MeHg) с последующим выделением в атмосферу. Следовательно, ртуть в экосистемах Севера имеет низкую концентрацию, находится в рассеянном состоянии и способна к активной миграции и аккумуляции на геохимических барьерах.

Уникальные эколого-геохимические свойства ртути (высокая токсичность и подвижность) позволяют ей мигрировать из одной среды в другую. Малые концентрации ртути стимулируют высокую биологическую активность живых организмов с коэффициентом накопления $10^{5}-10^{7}$ [7]. Начиная с определенного уровня, она становится токсичной: ПДК для питьевой воды составляет $0,0005 \mathrm{мг} /$ дм $^{3}$, для рыбохозяйственных водоемов - 0,00001 мг/дм ${ }^{3}$, для почв ПДК составляет 2,1 мг/кг, рыбы - 0,3-1,0 мг/кг.

Тундровые почвы являются крупнейшим источником поступления ртути в озера северной Аляски [11, 12]. Подробный анализ почв, проведенный на одиннадцати участках, показал снижение ее содержания в направлении от внутренних районов к прибрежным [13]. Это противоречит ожидаемому тренду, и поставило под сомнение вклад в биогеохимию региона атмосферного вымывания ртути $\mathrm{Hg}(\mathrm{II})$ вблизи побережья океана в первые месяцы после окончания полярной ночи [14].

Геохимия ртути высоких широт имеет свои особенности. Наблюдается массовое вымывание ртути из атмосферы в первые три месяца после восхода солнца в Антарктике [15, 16], Арктике [17, 18] Субарктике [19] и горных ледниках [20], что способствует значительному росту её концентрации в снегу и льдах (AMDE - Atmospheric Mercury Depletion Events). Положительная корреляция концентрации ртути и тропосферного озона $(+0,9)$ объяснима реакцией окис- ленной формы аэрозольной ртути атмосферы $\mathrm{Hg}(\mathrm{II})$ и активных галогенных радикалов $(\mathrm{BrO})$ из аэрозолей морской соли при воздействии солнечного света. Весной концентрации ртути возрастают в 1000 раз относительно зимнего периода вблизи побережья морей по сравнению с внутренними частями Арктики [18].

Созданы модели распределения ртути в атмосфере и снежном покрове при таянии в районе Канадского Севера [21]. Из моделей следует, что доля осажденной ртути, которая испаряется из снежного покрова, увеличивается с широтой с $28 \%$ между 30 и $45^{\circ}$ с. ш. до $51 \%$ с 45 до $66,5^{\circ}$ с.ш. и до $70 \%$ к северу от $66,5^{\circ}$ с. ш. в год. Средняя моделируемая концентрация ртути в стоках талой воды снежного покрова выше на европейской стороне (>20 нг/л) по сравнению с канадской ( $<10$ нг/л) побережья Северного Ледовитого океана. Наблюдения на арктической станции Андерма показали, что вымывание ртути из атмосферы происходит не только весной. В зимнее время оно возрастает вследствие осаждения влаги в виде кристаллов изморози [18]. Эффект AMDE ограничен расстоянием 200 м от побережья Карского моря.

В последние годы в канадской тундре проведено детальное изучение системы «атмосфера - снеговой покров - почва» [22]. В зимнее время отмечен устойчивый градиент снижения содержания $\mathrm{Hg}(0)$ в системе «атмосфера - верхний слой снега - нижний слой снега». Весной в снегу на удалении от океана наблюдается некоторый рост содержания ртути, что не оказывает значимого воздействия на тундровые экосистемы. Показано, что 70 \% ртути, выпадающей из атмосферы на ландшафты, является элементарной [9].

В условиях Севера происходит бактериальное метилирование ртути [5], кроме того, наблюдается и обратный процесс. В снегу и воде высокоолиготрофного пресноводного арктического озера под воздействием солнечного излучения доминирует разложение метилртути. Изучены микробные пути окислительного деметилирования ртути с диоксида углерода и с образованием метана в анаэробных условиях [23]. Для Арктики описаны циклы превращения ртути из $\mathrm{MeHg}$ в другие формы при участии фотоэффекта и ферментов бактерий - ртуть переходит в элементарное состояние $\operatorname{Hg}(0)$ и может испаряться с поверхности озер.

Большое значение в биогеохимии ртути в естественных ландшафтах имеют гумусовые вещества $[7,13,24]$. Фульвокислоты создают устойчивые растворимые комплексы, способствующие миграции ртути в водотоках; гуминовые кислоты, слаборастворимые в озерных и речных водах, способствуют её осаждению. Концентрация всех форм ртути проявляет положительную корреляцию с цветностью воды, обусловленной содержанием гумуса. В шведских озерах соотношение ртути и растворенного углерода ниже весной и летом $(0,45$ мг/г) и максимальны осенью $(0,8$ мг/г). Содержание всех форм ртути увеличивается с ростом кислотности (pH) с 7 до 5. Растворенные формы ртути сорбируются взвешенными частицами и за счет седиментации осаждаются на дно. Де- 
понирование ртути в донных отложениях позволяет оценивать уровни её миграционной активности.

Ранее установлено, что в донных отложениях содержание ртути убывает с глубиной, что косвенно указывает на её накопление в антропогенный период [25]. Также показано увеличение содержания ртути при движении от арктической тундры, северной тайги до средней тайги.

Актуальность изучения обусловлена тем, что исследования содержания ртути в донных отложениях озер Западной Сибири отрывочны [8]. Выводы часто делаются на малых выборках. В нашем исследовании предпринята попытка выявить закономерности пространственного и временного распределения содержания ртути в пределах одной природной зоны средней тайги. Акценты сделаны на изучении содержания ртути в озерах с разными ландшафтно-географическими условиями с использованием данных экологического мониторинга.

Целью исследования является анализ и обобщение фоновых мониторинговых наблюдений, как за общим содержанием ртути донных отложений, так и содержанием её в поверхностных водах озер, в зависимости от природных факторов в условиях средней тайги в пределах Ханты-Мансийского автономного округа.

Практический смысл работы заключается в том, что содержание ртути в донных отложениях не имеет определенного значения предельно допустимой величины (ПДК). Следовательно, чтобы оценивать загрязненность водоема ртутью необходимо знать фоновый уровень её концентрации. В некоторых случаях желательно предварительно прогнозировать его величину, используя систему ландшафтно-географических ориентиров.

\section{Объекты и методы исследования}

Территория располагается между $60^{\circ}$ и $65^{\circ}$ северной широты и попадает в Субарктику $\left(60^{\circ}-70^{\circ}\right.$ с. ш.). Она относится к средней тайге лесной зоны с ландшафтными провинциями: Ханты-Мансийская, Среднеобская, Сургутское полесье, Сибирские увалы. Для территории характерны годовой ход температуры континентального климата и очень высокая заболоченность, которая составляет 40\%, а в Сургутском полесье достигает $80 \%$. Озера широко распространены на территории Ханты-Мансийского автономного округа (ХМАО-Югры). На территории округа насчитывается 290 тыс. озер [26].

Погоду определяют циклоны, двигающиеся с севера-запада и запада округа. Весна длительная и отличается неустойчивой погодой с возвратами заморозков, переходом температуры через 0 градусов в течение суток. Лето непродолжительное, но теплое и влажное. Июль - самый жаркий месяц со среднемесячной температурой $+17{ }^{\circ} \mathrm{C}$, однако температура может подниматься до $+36{ }^{\circ} \mathrm{C}$. Самый холодный месяц - январь со среднемесячной температурой $19,4{ }^{\circ} \mathrm{C}$, абсолютным наблюдаемым минимум $-51^{\circ} \mathrm{C}$. Наступление зимних холодов обычно связано с антициклонами, формирующимися на юге, в Казахском мелкосопочнике, и на северо-востоке Центральной Сибири.

Для изучения фонового содержания ртути использованы данные материалов экологического мониторинга нефтяных месторождений в соответствии с принятыми для этого требованиями и методическими рекомендациями [27]. Отбор проб воды проводился в полиэтиленовую тару для быстрой транспортировки в лабораторию в соответствии с ГОСТ Р 51592-2000. Донные отложения озер отбираются из поверхностного слоя ила в полиэтиленовую тару для быстрой доставки в лабораторию. Химико-аналитические работы проведены методом атомно-адсорбционной спектрометрии (метод «холодного пара») в аккредитованной лаборатории (Центр лабораторного анализа и технических измерений по Уральскому федеральному округу ХМАО-Югры) в соответствии с ПНД Ф 14.1:2:4.160-2000 (Методика выполнения измерений массовой концентрации общей ртути в пробах природной, питьевой и сточной воды методом «холодного пара» на анализаторе ртути PA-915+ с приставкой РП-91). Для каждой пробы с помощью GPS определена широта и долгота.

Объем выборки составляет 95 озер, расположенных на значительном расстоянии от техногенных объектов. В некоторых объектах пробы отобраны в разные сезоны в течение трех лет. Однако есть озёра, в которых пробы отбирались только один раз. Выборка содержания ртути в донных отложениях составляет 332 пробы, в последующем для отдельных озер добавлены данные растворенной ртути (37 проб). Отбор проб охватывает период 2007-2011 гг.

Расположение ХМАО-Югры на карте России и изученных озер на территории ХМАО-Югры представлено на рис. 1.

Методический интерес представляют взаимосвязи с ландшафтно-географическими факторами: положение озер в ряду геохимической миграции вещества, окружающих компонентах ландшафта на уровне урочища, диаметр. Используя Google Earth pro, для всех озер проведена оценка их положения в макрорельефе: элювиальный, трансэлювиальный, супераквальный ландшафты. Ландшафт рассматривался в упрощённых геохимических координатах движения вещества. Озера, располагающиеся по линии водораздела и в непосредственной близи от неё, входили в первую категорию. Во вторую категорию отнесены те, которые располагаются в среднем течении малых рек, стекающих с водораздела. В третью категорию определены озера, располагающиеся на террасах крупных рек, в поймах и долинах рек.

Для каждого озера отмечаются почвенноэкологическое состояния окружающей местности: озерково-грядово-мочажинный комплекс, болото (без разделения по трофности), минеральные почвы. Компоненты ландшафта (на уровне урочища), окружающие изученные озера, относятся к олиготрофным среднетаежным элементам ландшафтов. Выделены следующие категории местностей, которые обозначены для каждого озера: 


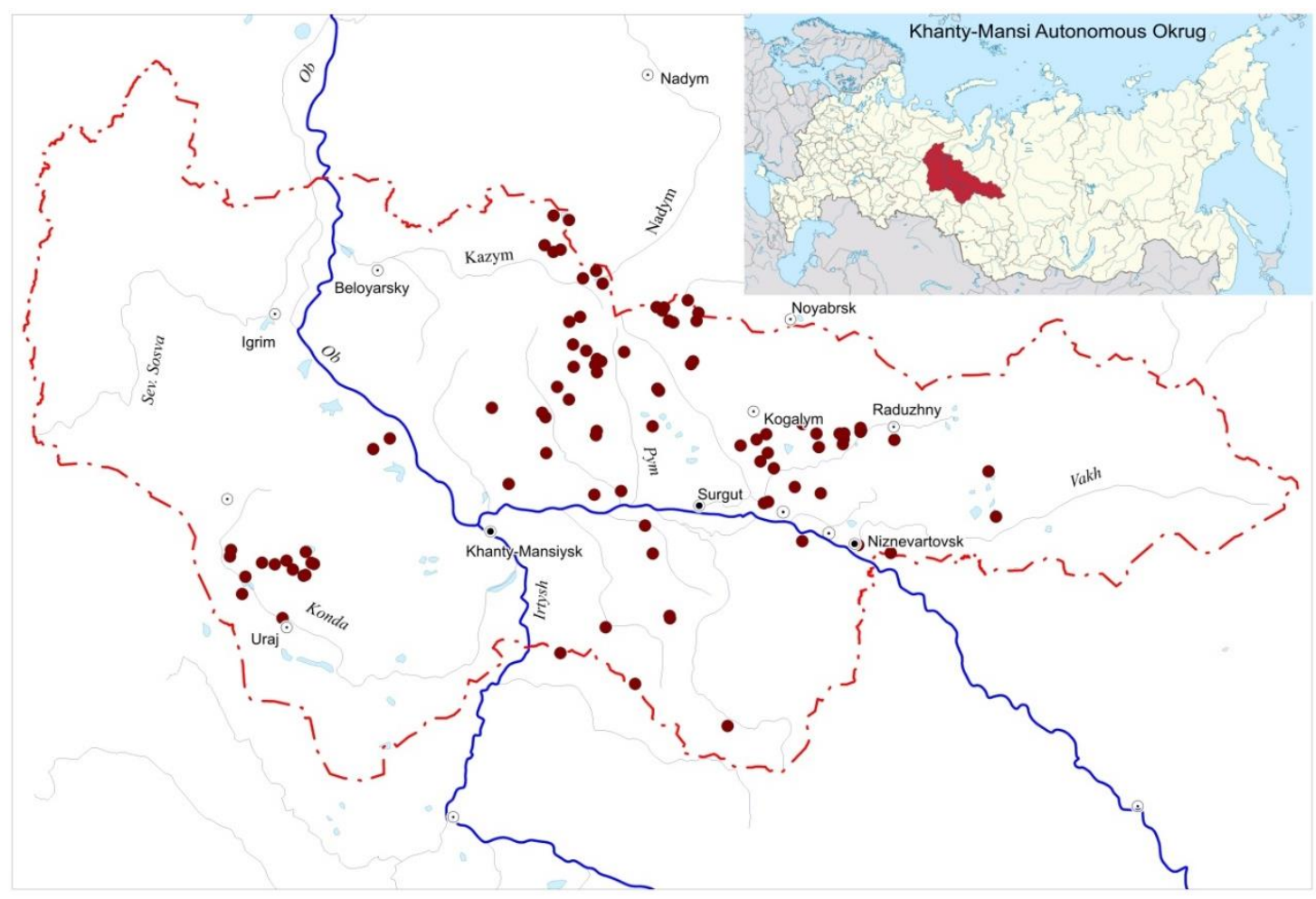

Pис. 1. Расположение ХМАО-Югры и изученных озер на карте России (Масштаб 1:60000). Условные обозначения:

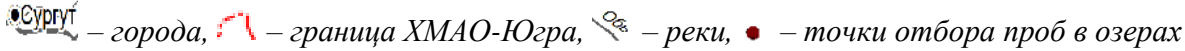

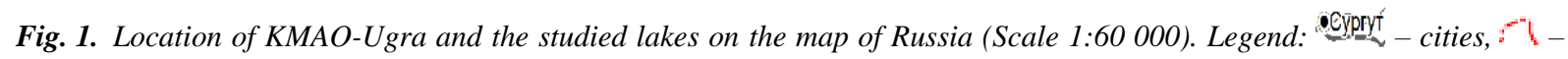
border of Khanty-Mansiysk district, $Y_{\bar{\delta}}$ - rivers, - - sampling site in lakes

- мочажинные комплексы (категория «ОГМК»), приуроченные к водораздельным пространствам, но они могут располагаться и на пологих склонах;

- озера, располагающиеся на верховых, переходных, или низинных болотах с невыраженными озерковыми комплексами, или зарастающие низинные болота, также среди рямов отнесены к категории «Болото»;

- озера, расположенные среди лесов, лугов, на поймах, отнесены к категории «Минеральные почвы». Важнейшей пространственной характеристикой является диаметр (км) озера. По этому признаку озера отнесены к пяти категориям, принятым в географии (км) [28]: малые - 0,1-0,5, средние - >0,5-1,5, большие $>1,5-3$, крупные - >3-6, очень крупные $>6$. Измерения диаметра проведены с использованием инструментов Google Earth pro.

Для каждой пробы отмечали сезон отбора. Традиционно рекомендуется проводить отбор проб по схеме: первый сезон - это зимняя межень (январь-март), второй сезон выделялся с апреля по июнь (половодье), третий - июль-сентябрь (летняя межень) и четвертый октябрь-декабрь (ледостав). В половодье отбор проб не проводился, в результате выделены три периода за сезон отбора проб: 1 - с декабря по апрель, 2 - с июня по август, 3 - с сентября по ноябрь. Наибольшее количество проб отбирается с июня по август.

Основой для изучения содержания ртути являлись те озера, которые подходят под определение фоновых наблюдений [27]. Если озера находятся вблизи куста скважин по добычи нефти, то выбираются только те, которые располагаются выше по рельефу, так, что воды от объекта загрязнения не могли попасть в водоем. Из выборки исключены все озера, расположенные на расстоянии до источников возможного выбросов ртути в атмосферный воздух менее 10 км. Исключались все места, расположенные вблизи поселков, центров переработки, транспортировки нефти, другие положения места отбора пробы, где может происходить сжигание топлива, попутного газа.

Для обработки данных использован программный пакет Statistica for Windows. Содержание ртути имеет логнормальное или степенное распределение, сильно сдвинутое к минимальным значениям, поэтому использованы методы анализа данных, такие как: медиана, непараметрический анализ Краскала-Уоллиса (Kruskal-Wallis ANOVA), при сравнении нескольких групп использован мультикомпозиционный коэффициент Z, достоверное значение которого подтверждает различие между отдельными группами. Использован критерий Манна-Уитни (u-критерий) при сравнении двух групп, например, зимние и летние заборы проб, а также ранговая корреляция Спирмена для обнаружения взаимосвязи между переменными, выраженные в цифровом формате.

\section{Результать}

Содержание ртути испытывает значительные колебания как в пространстве, так и во времени [28]. Иногда близко расположенные объекты существенно 
различаются по содержанию ртути в донных отложениях. Изменения во времени не велики для донных отложений, но могут в разы изменяться в случае растворенной ртути.

Основные статистические моменты, отражающие содержание ртути в донных отложениях: объем выборки, среднее арифметическое, доверительный интервал (р <0,05), медиана, мода, представлены в табл. 1.

Таблица 1. Общие статистические характеристики выборки ртути в донных отложениях и растворенной в воде озер

Table 1. General statistical characteristics of mercury sample in bottom sediments and dissolved in water in the water of the lakes

\begin{tabular}{|c|c|c|}
\hline $\begin{array}{c}\text { Характеристики } \\
\text { Characteristics }\end{array}$ & $\begin{array}{c}\text { Ртуть донных } \\
\text { отложений } \\
\text { Hg sediments }\end{array}$ & $\begin{array}{l}\text { Ртуть раство- } \\
\text { ренная } \\
\text { Dissolved } \mathrm{Hg} \\
\end{array}$ \\
\hline $\begin{array}{l}\text { Объем выборки } \\
\text { Sample size }\end{array}$ & 332 & 37 \\
\hline $\begin{array}{l}\text { Средняя концентрация, } \\
\text { мг/кг; мг/дм }{ }^{3} \\
\text { Average concentration , } \\
\mathrm{mg} / \mathrm{kg} ; \mathrm{mg} / \mathrm{dm}^{3}\end{array}$ & 0,046 & 0,025 \\
\hline $\begin{array}{l}\text { Доверительный интервал } \\
\mathrm{p}<0,05 \\
\text { Confidence interval p <0,05 }\end{array}$ & 0,012 & 0,014 \\
\hline $\begin{array}{l}\text { Медиана, мг/кг; мг/дм³ } \\
\text { Median } \mathrm{mg} / \mathrm{kg} ; \mathrm{mg} / \mathrm{dm}^{3}\end{array}$ & 0,05 & 0,013 \\
\hline $\begin{array}{l}\text { Мода, мг/кг; мг/дм³ } \\
\text { Mode } \mathrm{mg} / \mathrm{kg} ; \mathrm{mg} / \mathrm{dm}^{3}\end{array}$ & 0,05 & 0,01 \\
\hline
\end{tabular}

C точки зрения геохимии для миграции ртути имеет значение положение озера в макрорельефе. В элювиальной позиции она поступает в ландшафт как результат сухого и мокрого вымывания из атмосферы. Озера элювиальной и трансэлювиальной позиций в ландшафте по критерию Краскел-Уаллисне различаются между собой по содержанию ртути. Количество озер в супераквальном положении существенно меныше (55 озер) относительно элювиального (163 озер) и трансэлювиального (114 озер), но достаточно, чтобы выявить, что её содержание в супераквальной позиции ниже (при $\mathrm{p}<0,05)$ в сравнении с другими геоморфологическими позициями ландшафта. Высокое значение коэффициента $Z$ по критерию КраскелУаллисне подтверждает эти различия. Распределение содержания ртути существенно изменяется под влиянием природных факторов (табл. 2).

В случае содержания растворенной в воде ртути объем выборки оказывается недостаточным для выявления достоверных различий. Отмечаются тенденции, противоположные тому, что наблюдается в случае донных отложений озер: элювиальная позиция < трансэлювиальная < супераквальная.

Содержание ртути в донных отложениях озер, находящихся в разных ландшафтах (урочищах), различается по критерию Kruskal-Wallis. Различия между категориями значимы при $\mathrm{p}<0,05$. Наибольшее содержание ртути отмечается в ОГМК, меньше значение - для болота и наименьшее значение характерно для озер в окружении минеральных почв (при $\mathrm{p}<0,05)$. Достоверные значения коэффициента $\mathrm{Z}$ подтверждают эти различия. В экспоненциальной модели распределения $\mathrm{Hg}$ в донных отложениях наблюдается сжатие распределения содержания ртути как случайной величины в ряду ОГМК $>$ Болото $>$ Минеральные почвы. Между минеральными почвами и болотами различия недостоверны. Наибольшее значение содержания ртути имеет в ОГМК, наименьшее - в болотах (верховые, переходные, низинные без озерков), также наименьшее значение наблюдается на минеральных почвах. Для растворенной ртути отмечается обратная тенденция в ряду ОГМК $<$ Болото $<$ Минеральные почвы, но различия недостоверны из-за малочисленности выборки по некоторым категориям.

Таблица 2. Характеристики содержания ртути (мкг/кг) в донных отложениях озер, расположенных в разных позичиях ландшафта (элювиальной, трансэлювиальной и супераквальной), в урочище типа (ОГМК, болото, минеральные почвы)

Table 2. Characteristics of mercury concentration $(\mu \mathrm{g} / \mathrm{kg})$ in bottom sediments of lakes located in different positions of the landscape: eluvial, transeluvial and superaqual, in the land of the type: lakes complex, bog, mineral soils

\begin{tabular}{|c|c|c|c|c|}
\hline $\begin{array}{c}\text { Факторы } \\
\text { Factors (Variables) }\end{array}$ & 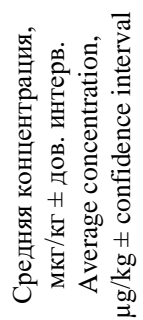 & 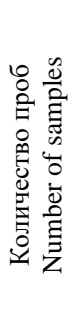 & 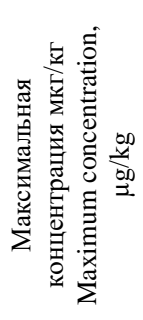 & 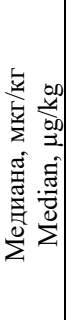 \\
\hline \multicolumn{5}{|c|}{ Положение в ландшафте/Positions in landscape } \\
\hline $\begin{array}{l}\text { Элювиальные } \\
\text { Eluvial }\end{array}$ & $50,5 \pm 8,5$ & 163 & 450 & 50,0 \\
\hline $\begin{array}{l}\text { Трансэлювиальные } \\
\text { Transeluvial }\end{array}$ & $47,7 \pm 11$ & 114 & 338 & 45,8 \\
\hline $\begin{array}{l}\text { Супераквальные } \\
\text { Superaqual }\end{array}$ & $22,7 \pm 7,3$ & 55 & 110 & 7,6 \\
\hline $\begin{array}{l}\text { Bсе группы } \\
\text { All groups }\end{array}$ & $44,9 \pm 5,8$ & 332 & 450 & 50,0 \\
\hline \multicolumn{5}{|c|}{ Местность/Land } \\
\hline $\begin{array}{l}\text { OГMК } \\
\text { Lakes complex }\end{array}$ & $52,3 \pm 9,6$ & 142 & 450 & 20,5 \\
\hline $\begin{array}{l}\text { Болото } \\
\text { Воg }\end{array}$ & $42,7 \pm 8,6$ & 150 & 338 & 5,0 \\
\hline $\begin{array}{l}\text { Минеральные почвы } \\
\text { Mineral soils }\end{array}$ & $27,2 \pm 8,8$ & 40 & 100 & 5,0 \\
\hline $\begin{array}{l}\text { Bce группы } \\
\text { Allgroups }\end{array}$ & $44,9 \pm 5,8$ & 332 & 450 & 5,6 \\
\hline
\end{tabular}

Размер озера не оказывает влияния на содержание ртути в донных отложениях, так, коэффициент корреляции Спирмена близок к нулю $(\mathrm{R}=0,09)$. Расчет по категориям размеров озер методом Kruskal-Wallis также не выявил достоверных различий. Очень крупные озера имеют низкое содержание ртути в донных отложениях, но эффект не выявляется из-за их небольшого количества в данной выборке (4 озера).

Отмечаются различия, обусловленные временем отбора пробы: зима - с декабря по апрель, лето - с 
июня по август, осень - с сентября по декабрь. Различия достоверны с высоким уровнем значимости (при $\mathrm{p}<0,05$ ) (рис. 2).

Наибольший размах колебаний концентрации ртути в донных отложениях наблюдается в зимний период, возрастая до максимума, летом значения снижаются до минимума и опять возрастают осенью. Дополнительно, чтобы исключить возможную методическую ошибку, вызванную методом расчета показа- телей, выборка разделена на два сезона: лето - с июня по сентябрь, зима - с ноября по апрель. Проведен непараметрический анализ Манна-Уитни с расчетом u-критерия, который дает более точную оценку относительно критерия Kruskal-Wallis. Анализ показывает достоверные различия концентрации ртути в донных отложениях - повышенные значения зимой и снижение летом.

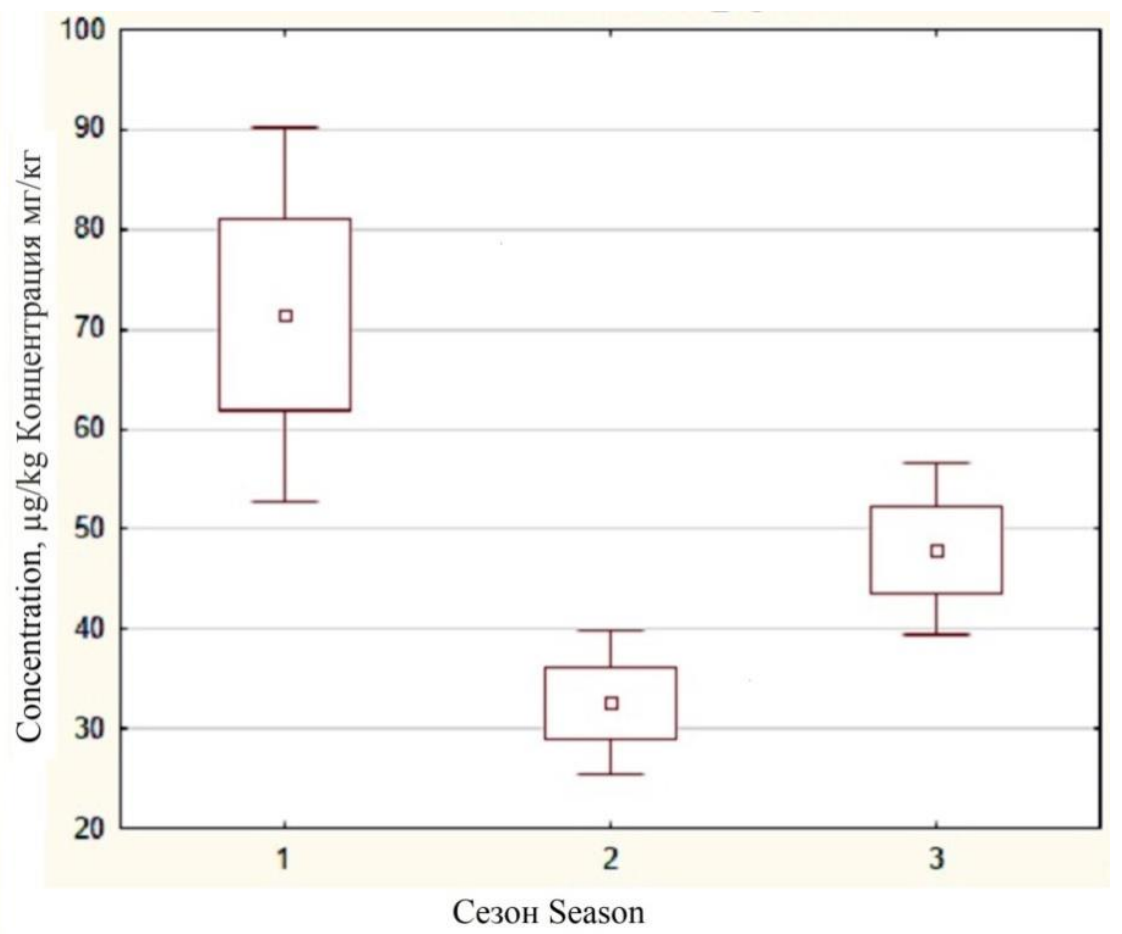

Pис. 2. Различия средних значений концентрачии ртути (мкг/кг) в донных отложениях озер в разные сезоны года: 1 - с декабря по апрель, 2 - с июня по август, 3 - с сентября по ноябрь

Fig. 2. Differences in average values of mercury concentration $(\mu \mathrm{g} / \mathrm{kg})$ in bottom sediments of lakes in different seasons of the year: 1 -from December to April, 2 -from June to August, 3 -from September to November

Растворенная ртуть имеет противоположную тенденцию относительно донного содержания. Максимальное содержание ртути в воде отмечается в летнюю межень, осенью ее концентрации снижаются, минимальные значения характерны для зимней межени. Различия между осенними и зимними содержаниями растворенной в воде ртути недостоверны.

Закономерности распространения по широте и долготе содержания ртути донных отложений и ртути, растворенной в воде озер, имеют разные направленности. Содержание ртути донных отложений увеличивается с юга на север, хотя значение коэффициента Спирмена составляет $r=0,4$ при $p<0,05$, но и при таком значении $\mathrm{r}$ линейная зависимость хорошо выражена. Из рис. 3 видно, что в этом направлении увеличиваются размеры кругов, отражающих градации концентрации ртути (рис. 3, А). Долготная зависимость отсутствует. Для растворенной ртути наоборот заметна тенденция увеличения ее содержания с запада на восток (рис. 3, В), и коррелирует с долготой $(\mathrm{r}=0,62$ при $\mathrm{p}<0,05)$. Коэффициент корреляции Спирмена высок, что отражается в размере кругов концен- трации растворенной ртути. Широтное значение коэффициента корреляции близко к нулю.

Использование фоновых наблюдений для сравнительного анализа содержания ртути на нефтяных месторождениях пока не представляется возможным, так как количество фоновых проб недостаточное для сравнительного анализа с использованием статистических методов.

\section{Обсуждение результатов}

Содержание ртути донных отложений и растворенная ее форма не коррелируют между собой, что кажется довольно странным явлением. Известно, что ртуть растворенная изменяется более динамично, наблюдается периодическое увеличение ее содержания, что не согласуется с более стабильной ситуацией в донных отложениях. Также сложно объяснить то, что содержание растворенной ртути в озерах не коррелирует с изменением ее содержания по широте, как в случае с донными отложениями. Более того, наблюдается положительная корреляция содержания растворенной ртути с долготой, выраженной в градусах, что отражает ее увеличение с запада на восток. 


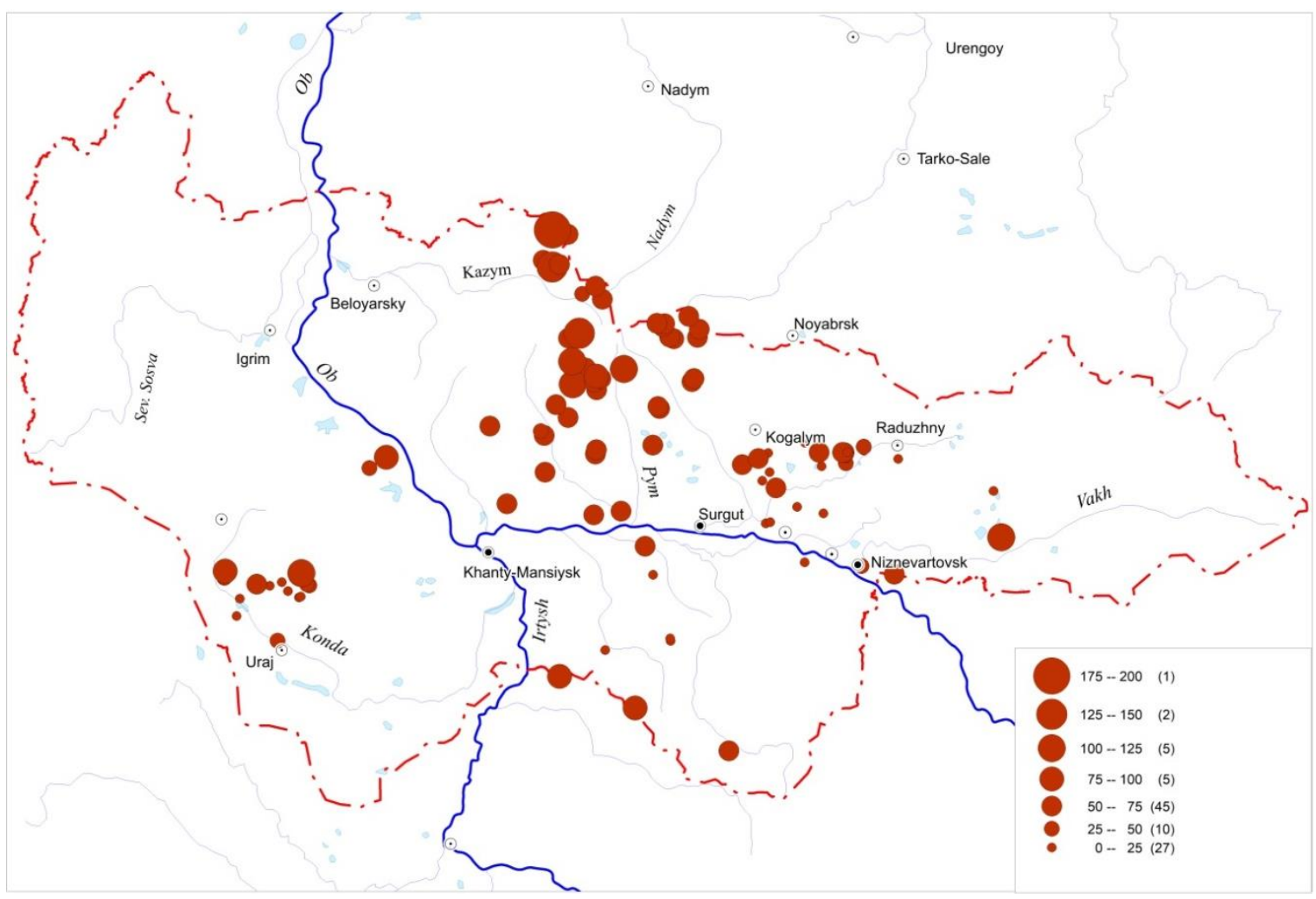

A

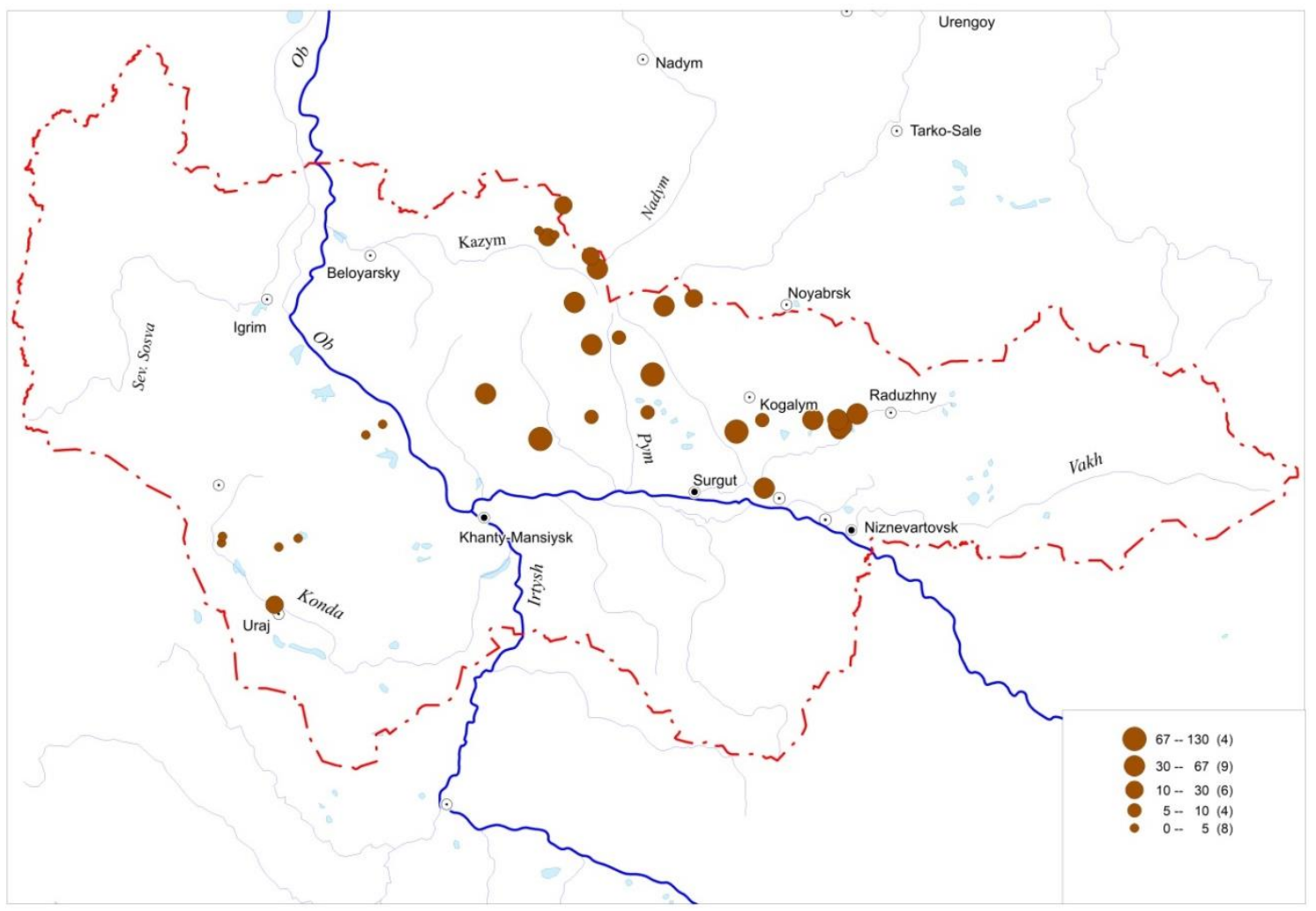

$\mathrm{B}$

Pис. 3. Пространственное различие в содержании $\mathrm{Hg}$ (A) в донных отложениях (мкг/кг), (В) растворенной ртути $\left(\right.$ мкг/дм $\left.{ }^{3}\right)$ (Ханты-Мансийский автономный округ). Размер точек соответствует диапазону градации концентрачии ртути, ичфры показывают интервал изменения, в скобках указаны количества проб в этом интервале (Масштаб 1:60000). Условные обозначения даны на рис. 1

Fig. 3. Spatial difference in $\mathrm{Hg}$ content $(A)$ in the bottom sediments lakes $(\mu \mathrm{g} / \mathrm{kg})$, (B) dissolved mercury $\left(\mu \mathrm{g} / \mathrm{dm}^{3}\right)(\mathrm{Khanty}$ Mansiysk region). The size of the points corresponds to the gradation of mercury concentration, the number of samples in this interval are in parentheses (Scale 1:60000). The legend is given in Fig. 1 
Исследованием охвачены озера центральной части Ханты-Мансийского автономного округа, расположенные на разных элементах ландшафта в различных урочищах. Донные отложения в озерах являются аккумуляторами ртутных загрязнений, поступающих из атмосферы. Геохимический Кларк ртути в почвах равнинной части Западной Сибири составляет 0,07 мг/кг $(0,08$ мг/кг для земной коры) [7, 29], а в донных отложениях наблюдается в среднем 0,05 мг/кг, что указывает на отсутствие условий для накопления ртути в осадках озер.

В Канаде (Toolik Field Station) отмечается снижение содержание ртути в почвах тундры при движении с юга на север, что связывают со снижением продуктивности биоценозов [13], следовательно, весеннее вымывание ртути из атмосферы не приводит к её увеличению в почвах. Предпринятый географический анализ ртути в пяти озерах [25], расположенных в тундре, северной тайге, средней тайге, показывает, что наблюдается существенное увеличение её содержания в этой географической системе с 0,022-0,029 до 0,101-0,127 мг/кг. Смущает, что всего в двух озерах подзоны средней тайги отбирались образцы донных отложений, что нельзя признать репрезентативным для обобщения на всю природную подзону. Статистически обоснованной средней величиной в пределах средней тайги ХМАО предлагается принять $0,046 \pm 0,012$ мг/кг. Однако вывод об увеличении содержания ртути в донных отложениях при переходе от тундры и северной тайги к средней тайге все равно подтверждается (увеличение почти в 2 раза). Объясняется это увеличением биологической активности и накоплением общего органического углерода в осадках. Известно, что зависимость содержания ртути в донных отложениях озер зависит от содержания общего органического углерода, и отражается на его содержание в рыбе [30]. В регионах, расположенных южнее, чем Ханты-Мансийский округ (юг Томской области), среднее содержание ртути в донных отложениях озер ещё больше и составляет 0,068 мг/кг, что соответствует местному региональному фону [31].

В элювиальных позициях макрорельефа территории ХМАО-Югры находятся верховые болота с грядово-мочажинным комплексом, для которых характерно повышенное содержание ртути, относительно супераквального положения, где преобладают минеральные почвы в окружении озер. Выявлено, что наибольшее содержание ртути характерно ОГМК $52,3 \pm 9,6$ мкг/кг. Установлено, что содержание ртути имеет минимальные значения в нижнем слое торфа верхового болота и увеличивается к поверхности [24]. Торф высокого ряма имеет более высокую концентрацию в верхнем 50 сантиметровом слое $(137,4 \pm 42,4$ мкг/кг), чем в осоково-сфагновой топи $(82,9 \pm 23,9$ мкг/кг) [27]. Содержание ртути в торфяниках Швеции существенно выше - 198,3 мкг/кг, а максимальные значения достигают от 130 до 460 мкг/кг [2] в органических горизонтах почв Канады. Исследование [12], проведенные в Канаде на Toolik Field Station в 200 км от побережья Северного Ледовитого океана, показывают, что в органических почвах средние значения концен- трации ртути составляет $99 \pm 6$ мкг/кг, за ними следует А-горизонты (65 \pm 8 мкг/кг), а самые низкие обнаружены в В-горизонтах ( $45 \pm 3$ мкг/кг). Следовательно, торф способствует накоплению ртути, что объясняет более высокое её содержание в донных отложениях озер, расположенных на заболоченных водоразделах по сравнению с таковыми среди минеральных почв. Этот факт объясняет наши результаты достоверно менышего содержание ртути в местах, где озера располагаются на минеральных почвах по равнению с болотистой местностью.

На территории ХМАО-Югры в пределах средней тайги с юга на север увеличивается пространство болот, занятое ОГМК, который располагается на верховых болотах и термокарстовых озерах. Показано, что термокарстовые озера имеют высокие скорости накопления ртути [31]. Для этого комплекса характерно повышенное содержание ртути в донных отложениях озер, что объясняет широтную зависимость с коэффициентом Спирмена $(\mathrm{r}=0,4)$. Поэтому в пределах географических зон Западной Сибири наблюдается рост содержания ртути в донных отложениях озер с севера на юг с увеличением содержания органического углерода [32, 33]. Но в географических подзонах могут наблюдаться противоположные тенденции, обусловленные ландшафтно-географическими особенностями территории, связанные с увеличением количества озер на верховых болотах.

Гораздо сложнее объяснить то, что содержание растворенной ртути в озерах не коррелирует ее содержания с широтой, как в случае донных отложений. Содержание ртути донных отложений и растворенная ее форма не коррелируют между собой, что кажется довольно странным явлением. Но ртуть растворенная изменяется более динамично, наблюдается периодическое увеличение ее содержания, что не согласуется с более стабильной ситуацией в донных отложениях. Более того, наблюдается положительная корреляция с долготой: увеличение содержания растворенной ртути с запада на восток. Известно так называемое «ртутное дыхание Земли», когда ртуть переносится гидротермальными растворами из мантии по разломам в земной коре и попадает в экосистемы [7, 33], что вызывает временное увеличение растворенной формы ртути. Тогда увеличение содержания растворенной ртути объясняется наличием глубинных разломов рифтовой зоны раннего Триаса, располагающегося на востоке ХМАО. Один из крупных разломов идет от г. Омска к г. Нижневартовску и далее на северо-восток согласно тектонической карте. Ртуть, поступающая из земных глубин, частично задерживается в растворимой форме в озерах.

Изучение распределения во времени содержания ртути в снежном покрове показало, что процесс весеннего вымывания ртути из атмосферы присутствует, но не приносит существенного увеличения её поступлении в тундровые экосистемы, что было показано на примере Toolik Field Station, Канада [22]. Исследования в ХМАО по распределению ртути по сезонам показывают, что в зимнюю межень наблюдается увеличение ртути в донных отложениях и снижение в 
растворенном состоянии. Предполагается, что процессы перегнивания в донных осадках приводят к увеличению органики и связыванию ею ртути с выпадением в осадок. Подробные исследования на Toolik Field Station, проведенные в 2015 г. показывают, что концентрация ртути в атмосфере и в верхнем слое снега более высокая, чем в глубине снегового слоя и на почве. Предполагается, что причиной такого распределения ртути в снеговом покрове является углекислый газ, который поступает из почвы снизу вверх, вытесняя ртуть к поверхности снега (рис. 4).
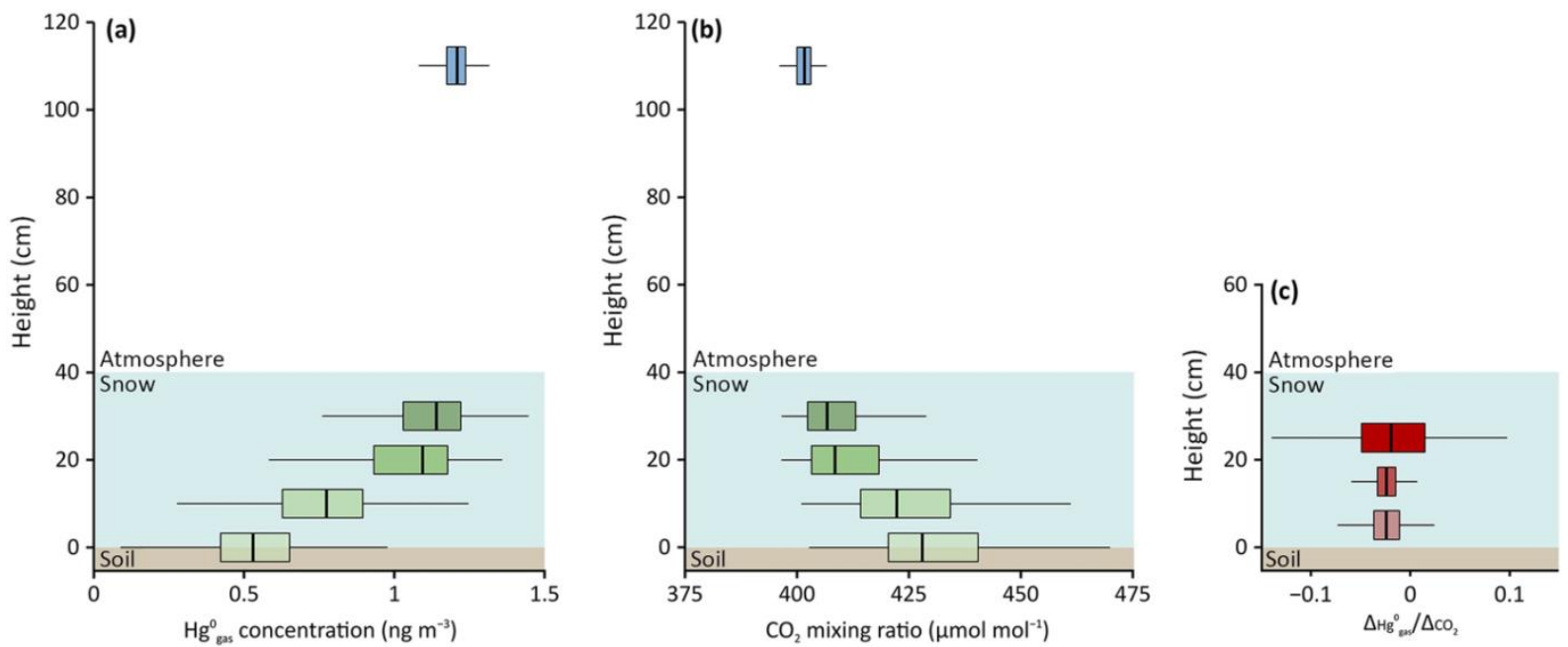

Pис. 4. Распределение концентрации газов $\mathrm{Hg}(0)\left(\right.$ (a) и $\mathrm{CO}_{2}$ (b) на глубинах в снеговом покрове (cм): 10, 20, 30 и атмосфере; отношение содержания ртути и $\mathrm{CO}_{2}$ в снеговом покрове (c) [22]

Fig. 4. Snow concentration profiles for $\mathrm{Hg}(0)$ gas $(a)$ and $\mathrm{CO}_{2}$ concentrations $(b)$ in snow cover and atmosphere and the ratio $\mathrm{Hg} / \mathrm{CO}_{2}($ c) [22]

Наше предположение о накоплении ртути в донных отложениях в зимнюю межень выдвинуто по аналогии тому, что наблюдается в снеговом покрове, но в обратном направлении движения ртути. Тем самым в озерах подо льдом с накоплением углекислоты создаются условия для аккумуляции ртути в илах и органике, так как выход в атмосферу для ртути и газов перекрыт. После таянья льда условия миграции ртути выравниваются, и её концентрация в донных отложениях озер снижается к летней межени.

\section{Выводы}

1. Таким образом, донные осадки содержат в среднем $0,046 \pm 0,012$ мг/кг ртути, растворенной ртути в озерах - 0,025 $\pm 0,014$ мг/дм ${ }^{3}$. Медиана концентрации ртути в донных отложениях составляет 0,05 мг/кг, а растворенной ртути - 0,013 мг/дм³. Значения их содержания ниже Кларка для горных пород $(0,07 \mathrm{Mг} / \mathrm{\kappa г)}$.

2. Выявлено, что концентрация ртути в озерах, pacположенных в элювиальном положении, выше, чем в озерах, расположенных в супераквальном положении, и различия достоверны $\mathrm{p}<0,05$. Трансэлювиальное положение озер близко с элювиальным положением по концентрации $\mathrm{Hg}$ в донных отложениях.

3. Установлено, что в донных отложениях озер, расположенных в озерково-грядо-мочажинном комплексе, концентрация ртути выше (при р <0,05), чем на минеральных почвах. Болота с грядами и мочажинами занимают в этом ряду среднее положение.
4. Следует признать наличие глобальной закономерности роста содержания ртути в донных отложениях озер в направлении от тундры, северной тайги к средней и южной тайге Западной Сибири. Однако в пределах подзоны средней тайги отмечается обратная тенденция. Рост концентрации ртути в донных отложениях с юга на север вызван увеличением площади болот озерково-грядовомочажинного комплекса.

5. Установлено, что концентрация ртути в донных отложениях в зимнюю межень существенно выше, чем в летний период. Разделение выборки на три категории по сезонам (зима, лето и осень) показывает низкое содержание ртути летом, среднее осенью и максимально в зимний период. Данная закономерность может быть вызвана осаждением илов, ростом содержания в них органики, накоплением растворенной углекислоты подо льдом, что в целом способствует выпадению ртути из раствора и ее накоплению в донных осадках.

6. Содержание растворенной ртути в озерах закономерно возрастает в восточном направлении, что можно связать с влиянием разломов земной коры на динамику содержания ртути. Содержание ртути в донных отложениях озер такой закономерности не подтверждает.

Работа выполнена при поддержке Российской Академии Наук, Базовая программа научных исследований SBRAS 2017-2020 (Projects VI.52.1.10.AAAA-A17-117050-400146-5) $u$ в рамках Программы повышения конкурентоспособности Томского политехнического университета. 


\section{СПИСОК ЛИТЕРАТУРЫ}

1. History of international collaboration on the exploration and development of the Arctic / O. Pasko, N. Staurskaya, A. Gryaznov, A. Zakharchenko // Handbook of Research on International Collaboration, Economic Development, and Sustainability in the Arctic. IGI Global Disseminator of Knowledge, 2018. A volume in the Practice, Progress, and Proficiency in Sustainability (PPPS) Book Series. Ch. 1. - P. 1-24. URL: https://docslide.us/documents/solidworks-flow-simulation-2012tutorial.html https://www.igi-global.com/chapter/history-ofinternational-collaboration-on-the-exploration-and-developmentof-the-arctic/218603 (дата обращения 11.05.2019).

2. Budnik L.T., Casteleyn L. Mercury pollution in modern times and its socio-medical consequences // The Science of the Total Environment. - 2019. - V. 654. - P. 720-734.

3. Biogeochemical cycling of methylmercury in lakes and tundra watersheds of Arctic Alaska / C.R. Hammerschmidt, W.F. Fitzgerald, C.H. Lamborg, P.H. Balcom, C.M. Tseng // Environ Sci. Technol. - 2006. - V. 40. - № 4. - P. 1204-1211.

4. Bindler R. Mired in the past - looking to the future: geochemistry of peat and the analysis of past environmental changes / // Global and Planetary Change. - 2006. - V. 53. - № 4. - P. 209-221

5. El-Hayek J., Mercury H. Contamination in Arctic Canada: possible implications for aboriginal health // Journal on Developmental Disabilities. - 2007. - V. 13. - № 1. - P. 67-89.

6. Оценка накопления ртути в объектах живой и неживой природы севера Европейской территории России / А.Э. Овсепян, Ю.А. Федоров, А.А. Зимовец, В.А. Савицкий // В мире научных открытий. - 2016. - Т. 5. - № 77. - С. 116-132.

7. Лапердина Т.Г. Определение ртути в природных водах. Новосибирск: Наука, 2000. - 222 с.

8. Long-term continuous monitoring of GEM in the ambient air on the Russian Arctic. Impact of the Eyjafjallajokull and Grimsvotn volcanic eruptions in Iceland / F. Pankratov, A. Mahura, O. Katz, A. Konoplev // Synopsis and Poster, Boundary Layers in High Latitudes: Physical and Chemical Processes Including Atmosphere-Ice Chemical Interactions (AICI). European Geosciences Union General Assembly 2012. - Vienna, Austria, April 22-27, 2012. - V. 14. DOI: 10.5194/acp-2018-1228.

9. Tundra uptake of atmospheric elemental mercury drives Arctic mercury pollution / D. Obrist, Y. Agnan, C.L. Olson, C.W. Moore, M. Jiskra, J.E. Sonke, D.P. Colegrove, J. Hueber, D. Helmig // Nature. - 2017. - V. 547. - № 7662. - P. 201-204. DOI: 10.1038/nature22997

10. Kumar A., Wu S. Mercury pollution in the Arctic from wildfires: source attribution for the 2000s // Environmental Science and Technology. - 2019. - V. 53. - № 19. - P. 11269-11275. DOI: doi.org/10.1021/acs.est.9b01773.

11. Modern and historic atmospheric mercury fluxes in northern Alaska: global sources and Arctic depletion / W.F. Fitzgerald, D.R. Engstrom, C.H. Lamborg, C.M. Tseng, P.H. Balcom, C.R. Hammerschmidt // Environ. Sci. Technol. - 2005. - V. 39. P. 557-568.

12. Mercury in active-layer tundra soils of Alaska: Concentrations, pools, origins, and spatial distribution / C. Olson, M. Jiskra, H. Biester, J. Chow, D. Obrist // Global Biogeochemical Cycles. 2018. - V. 32. - P. 1-16. DOI: 10.1029/2017GB005840.

13. The fate of mercury in Arctic terrestrial and aquatic ecosystems / T.A. Douglas, L. Loseto, R.R. Macdonald, P.M. Outridge // Environ. Chem. - 2012. - V. 9. - P. 321-355.

14. Mercury in the Canadian Arctic terrestrial environment: an update / M. Gamberg, J. Chételat, A. Poulain, C. Zdanowicz, J. Zheng // Science of the Total Environment. - 2015. - V. 3. - № 4. P. 509-510.

15. Dynamic oxidation of gaseous mercury in the Arctic troposphere at polar sunrise / S. Lindberg, S. Brooks, C. Lin, K. Scott, M. Landis, R. Stevens, M. Goodsite, A. Richter // Environ Sci Technol. - 2002. - V. 15. - № 36 (6). - P. 1245-1256.

16. Antarctic springtime depletion of atmospheric mercury / R. Ebinghaus, H.H. Kock, C. Temme, J.W. Einax, A.G. Lowe, A. Richter, J.P. Burrows, W.H. Schroeder // Environ Sci Technol. - 2002. - V. 15. - № 36 (6). - P. 1238-1244.
17. Dommergue A. Diurnal cycles of gaseous mercury within the snowpack at Kuujjuarapik, Whapmagoostui, Quebec, Canada // Environ Sci Technol. - 2003. - V. 37. - P. 3289-3297.

18. Фоновый мониторинг атмосферной ртути в российской Арктике и региона озера Байкал / Ф.Ф. Панкратов, А.Г. Махура, Ю.В. Корпусова, В.В. Милюков // Ртуть в биосфере: экологогеохимические аспекты: Сборник трудов Второго международного симпозиума. - Новосибирск: ИНХ СО РАН, 2015. $418 \mathrm{c}$.

19. Elevated mercury measured in snow and frost flowers near Arctic sea ice leads / T.A. Douglas, M. Sturm, W.R. Simpson, S. Brooks, S.E. Lindberg, D.K. Perovich // Geophysical research letters. $-2005 .-$ V. 32. - P. 1-4

20. Diurnal production of gaseous mercury in the alpine snowpack before snowmelt / X. Fain, S. Grangeon, E. Bahlmann, J. Fritsche // J. Geophys. Res. - 2007. - V. 112. - P. 1-12. DOI: 10.1029/2007JD008520.

21. How relevant is the deposition of mercury onto snowpacks? Part 2: A modeling study / D. Durnfor, A. Dastoor, A. Ryzhkov, L. Poissant, M. Pilote, D. Figueras-Nieto // Atmos. Chem. Phys. 2012. - V. 12. - P. 9251-9274. DOI: 10.5194/acpd-12-2647-2012.

22. Mercury in the Arctic tundra snowpack: temporal and spatial concentration patterns and trace gas exchanges / Y. Agnan, T. Douglas, D. Helmig, J. Hueber, D. Obrist // The Cryosphere. 2018. - V. 12. - P. 1939-1956. DOI: 10.5194/tc-12-1939-2018.

23. Barkay T., Poulain A.J. Mercury (micro) biogeochemistry in polar environments // FEMS Microbiology Ecology. - 2007. - V. 59. № 2. - P. 232-241.

24. Веретенникова Е.Э., Головацкая Е.А. Распределение свинца и ртути в торфяных залежах Западной Сибири (болота Васюганья) // Химия в интересах устойчивого развития. - 2012. № 20. - С. 181-187.

25. Особенности геохимического распределения валового содержания ртути в донных отложениях озер Западной Сибири / Н.В. Морозова, Н.С. Ларина, Т.П. Котова, Д.З. Шайхутдинова // Вестник Тюменского государственного университета Экология и природопользование. - 2015. - Т. 1. - № 1. - С. 65-73.

26. Лёзин В.А. Реки и озера Тюменской области (Словарьсправочник). - Тюмень: Пеликан, 1995. - 300 с.

27. Методические рекомендации по применению Требований к определению исходной (фоновой) загрязненности компонентов природной среды, проектированию и ведению системы экологического мониторинга в границах лицензионных участков недр на территории Ханты-Мансийского автономного округа. - Ханты-Мансийск: ГП «Полиграфист», 2004. - 92 с.

28. Виноградов А.П. Среднее содержание химических элементов в главных типах изверженных горных пород земной коры // Геохимия. - 1962. - № 7. - С. 555-571.

29. Kainz M., Lucotte M. Mercury concentrations in lake sediments revisiting the predictive power of catchment morphometry and organic matter composition // Water, Air, and Soil Pollution. February 2006. - V. 170. - № 1-4. - P. 173-189.

30. Иванов А.Ю., Губина К.А. Ртуть в донных отложениях слабопроточных водоемов юга Томской области // Ртуть в биосфере: эколого-геохимические аспекты. - Новосибирск: Изд-во ИНХ CO РAH, 2015. - С. 162-164.

31. Кравцова В.И., Родионова Т.В. Исследование динамики площади и количества термокарстовых озер в различных районах криолитозоны России по космическим снимкам // Криосфера Земли. - 2016. - Т. 20. - № 1. - С. 81-89.

32. Burke S.M., Zimmerman C.E., Branfireun B.A. Correction to: patterns and controls of mercury accumulation in sediments from three thermokarst lakes on the Arctic Coastal Plain of Alaska // Aquat Sci. - 2019. - V. 81. - № 5. URL: https://doi.org/10.1007/s00027-018-0601-4 (дата обращения 11.05.2019).

33. Мещеряков К.А., Карасева Т.В. Особенности формирования триасовых прогибов севера Западной Сибири в связи с нефтегазоносностью // Нефтегазовая геология. Теория и практика. 2010. - T. 5. - № 3. - C. 1-10. 


\section{Информация об авторах}

Захарченко A.B., доктор биологических наук, главный научный сотрудник, Тюменский научный центр Сибирского отделения Российской Академии Наук.

Пасько О.А., доктор сельско-хозяйственных наук, профессор отделения геологии Инженерной школы природных ресурсов Томского политехнического университета.

Tuгеeв A.A., кандидат географических наук, старший научный сотрудник, Тюменский научный центр Сибирского отделения Российской Академии Наук. 
UDC 57.044:550.46

\title{
IMPACT OF NATURAL FACTORS ON MERCURY IN LAKES OF THE NORTH OF WESTERN SIBERIA
}

\author{
Alexander V. Zakharchenko1, \\ ttruubbaa@mail.ru
}

\section{Olga A. Pasko²,} oap@tpu.ru

\author{
Alexander A. Tigeev 1 , \\ ttruubbaa@mail.ru \\ 1 Institute of problems of development of the North, \\ 86, Malygin avenue, Tyumen, 625026, Russia. \\ 2 National Research Tomsk Polytechnic University, \\ 30, Lenin avenue, Tomsk, 634050, Russia.
}

The relevance of the study is caused by the fact that mercury is involved in the global planetary biogeochemical cycle and is included in the food chain with the accumulation in organisms of predatory species of animals and in the indigenous population. With respect to Western Siberia, studies are fragmentary, and generalizations are made on small samples, which makes background studies of mercury content in the bottom sediments of lakes relevant in a representative sample.

The aim of the study is to analyze and generalize the background space-time observations of the gross mercury content in the bottom sediments, as well as dissolved, depending on natural factors in the middle taiga within the Khanty-Mansiysk Autonomous Okrug.

The object of study is the background concentration of dissolved $\mathrm{Hg}$ and mercury in the bottom sediments of lakes. 95 lakes, 322 samples of bottom sediments taken at different times were studied.

Methods: atomic absorption spectrometry («cold steam» method) determination of mercury in accredited laboratories in accordance with the guidelines. Background environmental monitoring data from 2007 to 2011 were used.

Result. The average background concentration of mercury in bottom sediments is 0,046 $\pm 0,012 \mathrm{mg} / \mathrm{kg}$, dissolved mercury - 0,025 $0,014 \mathrm{mg} / \mathrm{kg}$. The highest concentration of $\mathrm{Hg}$ was found in the eluvial and transeluvial positions, the lowest - in superaqueous landscapes. The concentration of $\mathrm{Hg}$ is maximum in lake-ridge-hollow complex of peat bogs and lowest - in the bottom sediments of lakes in mineral soils. There is a tendency to increase the concentration of mercury in the bottom sediments of lakes from the tundra zone, the Northern taiga to the subzone of the middle taiga. However, bogging increases from south to north, which contributes to increase in mercury content in lake bottom sediments $(R=0,4)$. There is an increase in dissolved mercury in lakes from West to East (longitude) $(R=0,6)$. The assessment of changes in mercury content in bottom sediments suggests that mercury content is higher in winter than in summer. The concentration of dissolved mercury increases from west to east, but mercury from bottom sediments is not consistent with this.

\section{Key word:}

Mercury, sediments, lakes, landscape-geographical factors, dynamics, Subarctic

This work was supported by the Russian Academy of Sciences, Basic Research Program SB RAS 2017-2020 (Projects VI.52.1.10. AAAA-A17-117050-400146-5) and is carried out at National Research Tomsk Polytechnic University within the framework of Tomsk Polytechnic University Competitiveness Enhancement Program.

\section{REFERENCES}

1. Pasko O., Staurskaya N., Gryaznov A., Zakharchenko A. History of international collaboration on the exploration and development of the Arctic. Handbook of Research on International Collaboration, Economic Development, and Sustainability in the Arctic. IGI Global Disseminator of Knowledge, 2018. pp. 1-23. Available at:: https://docslide.us/documents/solidworks-flow-simulation-2012tutorial.html https://www.igi-global.com/chapter/history-ofinternational-collaboration-on-the-exploration-and-developmentof-the-arctic/218603 (accessed 11 May 2019).

2. Budnik L.T., Casteleyn L. Mercury pollution in modern times and its socio-medical consequences. The Science of the Total Environment, 2019, vol. 654, pp. 720-734.

3. Hammerschmidt C.R., Fitzgerald W.F., Lamborg C.H., Balcom P.H., Tseng C.M. Biogeochemical cycling of methylmercury in lakes and tundra watersheds of Arctic Alaska. Environ Sci Technol, 2006, vol. 40, no. 4, pp. 1204-1211.

4. Bindler R. Mired in the past - looking to the future: geochemistry of peat and the analysis of past environmental changes. Global and Planetary Change, 2006, vol. 53, pp. 209-221.
5. El-Hayek J.H. Mercury contamination in Arctic Canada: possible implications for aboriginal health. Journal on Developmental Disabilities, 2007, vol. 13, no. 1, pp. 67-89.

6. Ovsepyan A.E., Fedorov Yu.A., Zimovets A.A., Savitsky V.A. Estimation of mercury accumulation in the objects of animate and inanimate nature in the north of European Russia. World of Scientific Discoveries, 2016, vol. 77, no. 5, pp. 116-132. In Rus.

7. Laperdina T.G. Opredelenie rtuti v prirodnykh vodakh [Mercury determination in Natural Wates]. Novosibirsk, Nauka Publ., 2000. $222 \mathrm{p}$.

8. Pankratov F., Mahura A., Katz O., Konoplev A. Long-term continuous monitoring of GEM in the ambient air on the Russian Arctic. Impact of the Eyjafjallajokull and Grimsvotn volcanic eruptions in Iceland. Synopsis and Poster, Boundary Layers in High Latitudes: Physical and Chemical Processes Including Atmosphere-Ice Chemical Interactions (AICI). European Geosciences Union General Assembly 2012. Vienna, Austria, April 22-27, 2012. Vol. 14, DOI: 10.5194/acp-2018-1228.

9. Obrist D., Agnan Y., Olson C.L., Moore C.W., Jiskra M., Sonke J.E., Colegrove D.P., Hueber J., Helmig D. Tundra uptake of atmospheric elemental mercury drives Arctic mercury pollution. 
Nature, 2017, vol. 547, no. 7662, pp. 201-204. DOI: 10.1038/nature22997

10. Kumar A., Wu S. Mercury pollution in the Arctic from wildfires: source attribution for the 2000s. Environmental Science and Technology, 2019, vol. 53, no. 19, pp. 11269-11275. DOI: doi.org/10.1021/acs.est.9b01773.

11. Fitzgerald W.F., Engstrom D.R., Lamborg C.H., Tseng C.M., Balcom P.H., Hammerschmidt C.R. Modern and historic atmospheric mercury fluxes in northern Alaska: global sources and Arctic depletion. Environ. Sci. Technol., 2005, vol. 39, pp. 557-568.

12. Olson C., Jiskra M., Biester H., Chow J., Obrist D. Mercury in active-layer tundra soils of Alaska: Concentrations, pools, origins, and spatial distribution. Global Biogeochemical Cycles, 2018, vol. 32, pp. 1-16.

13. Douglas T.A., Loseto L., Macdonald R.R., Outridge P.M. The fate of mercury in Arctic terrestrial and aquatic ecosystems. Environ. Chem, 2012, vol. 9, pp. 321-355.

14. Gamberg M., Chételat J., Poulain A.J., Zdanowicz C., Zheng J. Mercury in the Canadian Arctic terrestrial environment: an update. Science of the Total Environment, 2015, vol. 15, no. 6, pp. 509-510.

15. Lindberg S.E., Brooks S., Lin C.J., Scott K.J., Landis M.S., Stevens R.K., Goodsite M., Richter A. Dynamic oxidation of gaseous mercury in the Arctic troposphere at polar sunrise. Environ Sci Technol, 2002, vol. 36, no. 6, pp. 1245-1256.

16. Ebinghaus R., Kock H.H., Temme C., Einax J.W., Lowe A.G., Richter A., Burrows J.P., Schroeder W.H. Antarctic springtime depletion of atmospheric mercury. Environ Sci Technol, 2002, vol. 36, pp. 1238-1244.

17. Dommergue A. Diurnal cycles of gaseous mercury within the snowpack at Kuujjuarapik, Whapmagoostui, Quebec, Canada. Environ Sci Technol, 2003, vol. 37, pp. 3289-3297.

18. Pankratov F.F., Makhura A.G., Korpusova Yu.V., Milyukov V.V. Fonovy monitoring atmosfernoy rtuti v rossiyskoy Arktike i regiona ozera Baykal [Background monitoring of atmospheric mercury in the Russian Arctic and the lake Baikal region]. Rtut v biosfere: ekologo-geokhimicheskiye aspekty [Mercury in the biosphere: ecological and geochemical aspects]. Novosibirsk, INKH SO RAN Publ., 2015. pp. 283-287.

19. Douglas T.A. Elevated mercury measured in snow and frost flowers near Arctic sea ice leads. Geophysical research letters, 2005, vol. 32, pp. 1-4.

20. Fain X. Diurnal production of gaseous mercury in the alpine snowpack before snowmelt. J. Geophys. Res., 2007, vol. 112, pp. $1-12$.

21. Durnfor D., Dastoor A., Ryzhkov A., Poissant L., Pilote M., Figueras-Nieto D. How relevant is the deposition of mercury onto snowpacks? P. 2: A modeling study. Atmos. Chem. Phys., 2012, vol. 12, pp. 9251-9274. DOI: 10.5194/acpd-12-2647-2012.

22. Agnan Y., Douglas T.A., Helmig D., Hueber J., Obrist D. Mercury in the Arctic tundra snowpack: temporal and spatial concentration patterns and trace gas exchanges. The Cryosphere, 2018, vol. 12, pp. 1939-1956. DOI: 10.5194/tc-12-1939-2018.

23. Barkay T., Poulain A.J. Mercury (micro) biogeochemistry in polar environments. FEMS Microbiology Ecology, 2007, vol. 59, no. 2, pp. 232-241.

\section{Information about the aurhors}

Alexander V. Zakharchenko, Dr. Sc. principle scientific researcher, Institute of problems of development of the North, Siberian Branch of the Russian Academy of Sciences.

Olga A. Pasko, Dr. Sc., professor, National Research Tomsk Polytechnic University.

Alexander A. Tigeev, Cand. Sc., senior scientist, Institute of problems of development of the North, Siberian Branch of the Russian Academy of Sciences.
24. Veretennikova E., Golovatskaya E.A. Raspredelenies svintsa i rtuti $\mathrm{v}$ torfyanykh zalezhakh Zapadnoy Sibiry (bolota Vasyuganya) [Lead and mercury distribution in peat deposits of Western Siberia (Vasyugan swamps)]. Khimiya $v$ interesakh ustoychivogo razvitiya, 2012, vol. 20, pp. 181-187.

25. Morozova N.V., Larina N.S., Kotova T.P. Features of the geochemical distribution of the gross content of mercury in sediments of lakes in Western Siberia. Vesntik TSU. Ecology and nature management, 2015, vol. 1, no. 1 (1), pp. 65-73. In Rus.

26. Lezin V.A. Reki i ozera Tyumenskoy oblasti (slovar-spravochnik) Handbook)]. Tyumen, Pelikan Publ., 1995. 300 p.

27. Metodicheskie rekomendacii po primeneniyu Trebovaniy $k$ opredeleniyu iskhodnoy (fonovoy) zagryaznennosti komponentov prirodnoy sredy, proektirovaniyu $i$ vedeniyu sistemy ekologicheskogo monitoringa $v$ granitsah litsenzionnykh uchastkov nedr na territorii Khanty-Mansiyskogo avtonomnogo okruga [Guidelines for application of the Requirements for determining the initial (background) pollution of environmental components, designing and maintaining an environmental monitoring system within the boundaries of licensed subsoil areas in the Khanty-Mansi Autonomous Area]. Khanty-Mansiysk, GP «Poligrafist» Publ., 2004. $92 \mathrm{p}$.

28. Vinogradov A.P. Average content of chemical elements in the main types of igneous rocks of the earth's crust. Geochemistry, 1962, no. 7, pp. 555-571. In Rus.

29. Kainz M., Lucotte M. Mercury concentrations in lake sediments - revisiting the predictive power of catchment morphometry and organic matter composition. Water, Air, and Soil Pollution, February 2006, vol. 170, Iss. 1-4, pp. 173-189.

30. Ivanov A.Yu., Gubina K.A. Rtut v donnykh otlozheniyakh slaboprotochnykh vodoemov yuga Tomskoy oblasti [Mercury in bottom sediments of low-flow reservoirs in the south of Tomsk region]. Rtut v biosfere: ekologo-geokhimicheskie aspekty [Mercury in the biosphere: ecological and geochemical aspects]. Novosibirsk, INKh SB RAS Publ., 2015. pp. 162-164.

31. Kravtsova V.I., Rodionova T.V. Investigation of the dynamics in area and number of thermokarst lakes in various regions of Russian chryolithozone, using satellite images. Earth cryosphere, 2016, vol. 20, no. 1, pp. 81-89. In Rus.

32. Burke S.M., Zimmerman C.E., Branfireun B.A. Correction to: patterns and controls of mercury accumulation in sediments from three thermokarst lakes on the Arctic Coastal Plain of Alaska. Aquat Sci, 2019, vol. 81, no. 5. Available at: https://doi.org/10.1007/s00027-018-0601-4 (accessed 11 May 2019).

33. Meshcheryakov K.A., Karaseva T.V. Features of the formation of the Triassic troughs of the north of Western Siberia in connection with oil and gas content. Oil and gas geology. Theory and practice, 2010, vol. 5, no. 3, pp. 1-10. In Rus.

Received: 2 December 2019. [The rivers and lakes of the Tyumen region (Dictionary- 